\title{
Indicators of Sustainable Entrepreneurial Ecosystems
}

\author{
Dmitry Zavyalov, Yury Saginov, Nadezhda Zavyalova, Olga Saginova* \\ Plekhanov Russian University of Economics, Moscow, Russia \\ "Corresponding author.Email: saginova.ov@rea.ru

\begin{abstract}
The purpose of this paper is to develop a system of indicators for assessing the effectiveness of entrepreneurial ecosystems based on platform solutions. These indicators can further be used as a mechanism for tracking the ongoing transformations in business environment. Scientific publications, normative legal acts, and analytical materials of Russian, foreign and international organizations served as a methodological basis of the research. The proposed principles of forming a system of indicators take into account the possibility of achieving the objectives of the entrepreneurial ecosystem and increasing the value created within the ecosystem.
\end{abstract}

Keywords: Entrepreneurial ecosystem, network, sustainable development, indicators, digital platforms

\section{INTRODUCTION}

Global business environment is now shifting to platform solutions and ecosystems that provide new opportunities for sustainable development. The ecosystem is an example of multilateral cooperation that cannot be decomposed into several bilateral interactions. In an ecosystem, the analysis of bilateral relations of actors can lead to false conclusions about the effectiveness or efficiency of interactions occurring in several directions at once, and it is impossible to isolate any actors and analyze only the selected interactions [1]. To assess the performance of an ecosystem it is necessary to have a system of indicators assessing both individual results of the participating actors, and the overall effectiveness of interaction within the ecosystem.

Digital platforms often act as a central element of the value creation process through organizing and coordinating the process of multilateral interaction between businesses within the same ecosystem. An important goal for modern ecosystem interaction is to support the sustainability of business processes, create value for businesses and satisfy consumer demand without compromising the livelihood of the future generations.

The analysis of scientific publications shows that the business environment or the context for creating consumer value is undergoing radical transformations today, making obsolete the established models and constructs of business environment analysis. The complex nature of the business environment is analysed by the market theories, sociology, and various concepts of strategic management [2][3][4][5][6][7][8][9].

The ecosystem concept considers not only actors directly involved in the value chain, such as suppliers or customers, but also all actors who form the value chain, even indirectly. The ecosystem concept includes tangible and intangible assets such as infrastructure, institutions, knowledge and network effects of the interaction.

Though a significant number of scientific publications are devoted to the issues of assessing the sustainability of entrepreneurial systems of various scales [10][11], there is no clear evidence of a set of indicators to assess interaction and added value for a business to become part of the ecosystem. The purpose of this research is to develop a system of indicators for assessing the effectiveness of entrepreneurial ecosystems based on platform solutions, which could become a mechanism for tracking the ongoing transformations in the business environment.

\section{MATERIALS AND METHODS}

Using research publications and analytical reports of consulting companies data was collected as to the value created by platform-based ecosystems for their participants, the ecosystem itself, consumers and society at large. Results are presented in Table 1. Further on this value was translated into indicators to measure the progress towards the goals set. Another round of analysis was focused on the risks involved in ecosystem participation, comparing the benefits of interaction with the risks of additional regulation and governance. Both 
Table 1. Value created by an ecosystem based on platform solutions

\begin{tabular}{|c|c|c|c|}
\hline $\begin{array}{l}\text { Value to the end } \\
\text { consumer }\end{array}$ & Value for actors & $\begin{array}{l}\text { Value for the business ecosystem in } \\
\text { the sphere of commodity circulation }\end{array}$ & Social value \\
\hline $\begin{array}{l}\text { Reducing the cost of } \\
\text { goods and services } \\
\text { through the network } \\
\text { structure of the } \\
\text { entrepreneurial } \\
\text { ecosystem }\end{array}$ & $\begin{array}{l}\text { Increased revenue from } \\
\text { an increased customer } \\
\text { base. Access to new } \\
\text { markets }\end{array}$ & $\begin{array}{l}\text { Increased opportunity to manage the } \\
\text { sustainable development of the } \\
\text { commodity circulation sphere } \\
\text { through the involvement of national } \\
\text { producers in the sphere of } \\
\text { commodity circulation }\end{array}$ & $\begin{array}{l}\text { Increasing the level of } \\
\text { national food security }\end{array}$ \\
\hline $\begin{array}{l}\text { Lower cost of } \\
\text { goods/services }\end{array}$ & $\begin{array}{l}\text { Cost reduction } \text { through } \\
\text { resource sharing. Sharing } \\
\text { of research and } \\
\text { development costs }\end{array}$ & $\begin{array}{l}\text { Increased impact of the } \\
\text { entrepreneurial ecosystem on the } \\
\text { environment }\end{array}$ & $\begin{array}{l}\text { Improvement of ecological } \\
\text { situation in the region due } \\
\text { to joint use of material } \\
\text { resources by the actors }\end{array}$ \\
\hline $\begin{array}{l}\text { Improved quality of } \\
\text { goods and services }\end{array}$ & $\begin{array}{l}\text { Opportunity to use new } \\
\text { knowledge to improve the } \\
\text { quality of products and } \\
\text { services to increase } \\
\text { competence }\end{array}$ & $\begin{array}{l}\text { Formation of modern entrepreneurial } \\
\text { culture focused on economic, } \\
\text { environmental and social aspects. } \\
\text { Offers of a wide range of goods and } \\
\text { services }\end{array}$ & $\begin{array}{l}\text { Sustainability } \\
\text { commodity circulation }\end{array}$ \\
\hline $\begin{array}{l}\text { Availability of goods } \\
\text { and services through the } \\
\text { use of platform } \\
\text { ecosystem resources }\end{array}$ & $\begin{array}{lrr}\begin{array}{l}\text { Opportunity } \\
\text { markets }\end{array} & \text { to } & \begin{array}{r}\text { expand } \\
\text { through }\end{array} \\
\text { ecosystem } & \text { platform } \\
\text { resources } & \end{array}$ & $\begin{array}{l}\text { Transparency in doing business. } \\
\text { Access to the core skills of actors to } \\
\text { implement flexible procedures for } \\
\text { responding to challenges and } \\
\text { business opportunities }\end{array}$ & $\begin{array}{l}\text { Equalization of the } \\
\text { regional development } \\
\text { level. Accessibility of } \\
\text { goods and services in the } \\
\text { distributed system of tare } \\
\text { circulation }\end{array}$ \\
\hline $\begin{array}{l}\text { Reducing risks of lack of } \\
\text { availability of } \\
\text { goods/services }\end{array}$ & $\begin{array}{l}\text { Reducing the risks of } \\
\text { interactions } \\
\text { suppliers of goods and } \\
\text { services } \\
\text { information } \\
\text { Greater agility }\end{array}$ & $\begin{array}{l}\text { Reduction of risks of negative } \\
\text { trajectory } \\
\text { structures }\end{array}$ & $\begin{array}{l}\text { Increase in } r \text { the } \\
\text { involvement level of } \\
\text { business entities in the } \\
\text { sphere of commodity } \\
\text { circulation }\end{array}$ \\
\hline $\begin{array}{l}\text { Use of goods/services } \\
\text { provided by reputable } \\
\text { companies }\end{array}$ & $\begin{array}{ll}\text { Sharing } & \text { social } \\
\text { responsibility } & \end{array}$ & Development of social responsibility & $\begin{array}{l}\text { Development of social } \\
\text { responsibility }\end{array}$ \\
\hline
\end{tabular}

research and review publications from ScienceDirect by Elsevier analysing the goals, process, and results of network interaction within ecosystems were collected. Finally, the results were set against the triple objectives of sustainable development to identify ways to measure intra-network interaction between ecosystem actors.

The creation of entrepreneurial networks has become not only a tool for attracting, but also a mechanism for retaining customers, primarily on the basis of increasing the competitiveness of both network participants and the whole ecosystem. Impact factors influencing the increase of the entrepreneurial ecosystem effectiveness are being discussed by researchers in different sectors of economy [10][11][12][13].

The recognition of the ecosystem concept and its rapid spread in economics and management can be explained by the need for new approaches to economic analysis at the aggregate level, the possibility of considering the interrelationships of the management object with various actors and interaction of actors within entrepreneurial ecosystems [14][15][16]. To conduct a core value alignment analysis, it is necessary to identify (1) a list (structure) of core values; (2) shared values among network actors; (3) a set of core values related to one organization that have a positive or negative impact on another set of core values related to another organization [17], see Table 1.

The choice of indicators for assessing the interaction between actors in the entrepreneurial ecosystem is a topic of active scientific discourse. Currently, research on this issue is conducted from two different angles: the position of ecosystem actors [18] or ecosystem leaders [19], and the sustainable development of the ecosystem itself. The system of indicators should reflect the development of connections and interactions of actors within the platform ecosystem [20] [21], its sustainable development not only in economic, but also in social and environmental aspects[22][23][24] [21], as well as reflect the transformation processes in the distributed use economy represented by the platform based ecosystems [25].

\section{RESULTS AND DISCUSSION}

When evaluating the effectiveness of entrepreneurial ecosystems, indicators should reflect the specific characteristics of the ecosystem and its structure (Figure $1)$.

There are independent and dependent focal networks with different level of independence of their actors. Independent focal networks have a high degree of independence in financial terms; the self-organization 


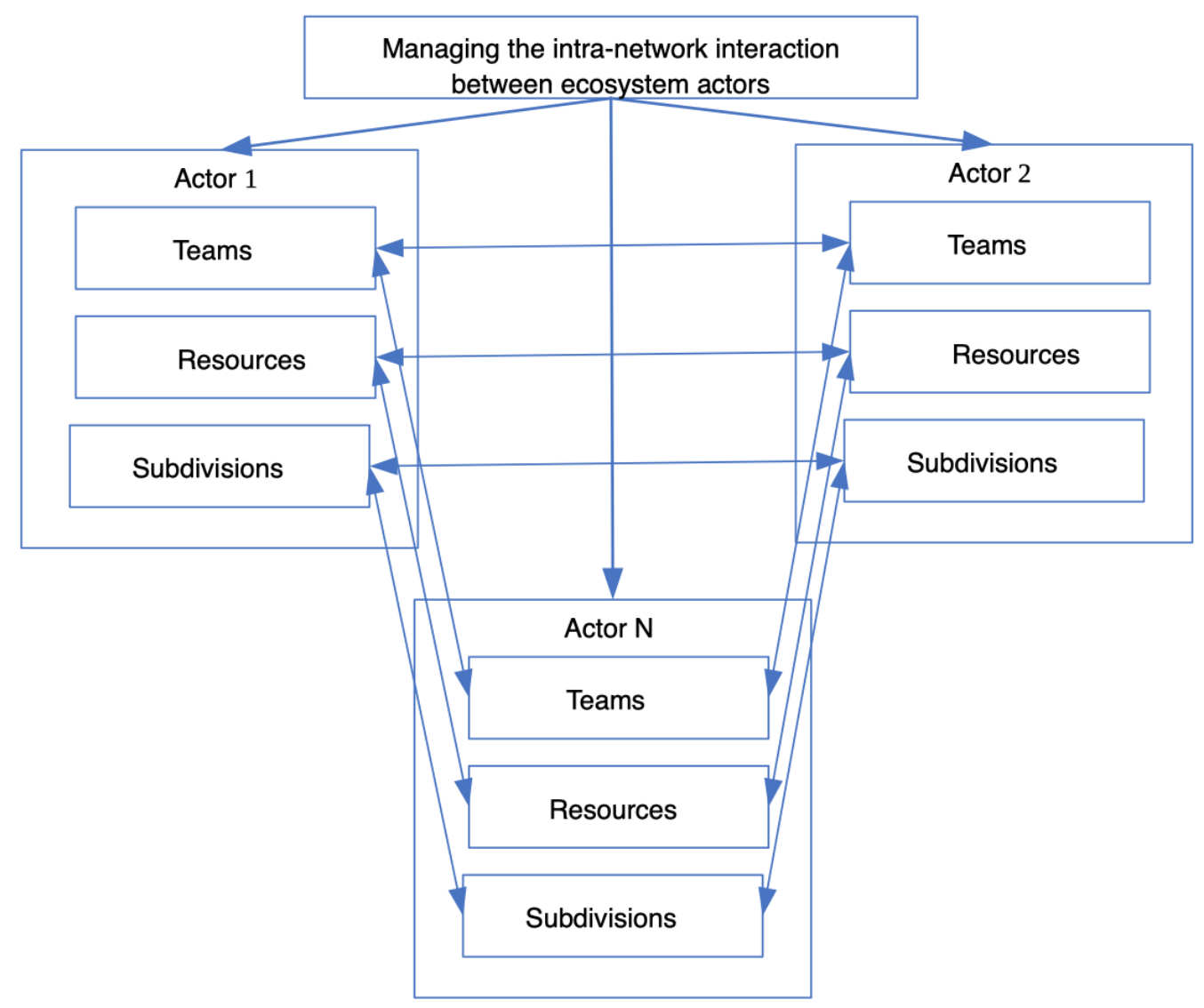

Figure 1 Organization of internal interaction between ecosystem actors in the sphere of commodity circulation

Table 2 Problems and risks of entrepreneurial networks based on platform solutions

\begin{tabular}{|l|l|}
\hline Problems & Risks \\
\hline $\begin{array}{l}\text { The possibility of monopolizing power functions by a platform organizer } \\
\text { or a key actor. In a network structure, this will lead to increased } \\
\text { institutionalization, increased structuration, and loss of the principal } \\
\text { properties of the network }\end{array}$ & $\begin{array}{l}\text { The ability of individual actors to manipulate } \\
\text { the terms of participation in a network } \\
\text { entrepreneurial structure to achieve their own } \\
\text { goals }\end{array}$ \\
\hline Potentially lower governability & $\begin{array}{l}\text { Risk of loss of management efficiency because } \\
\text { of high dependency on information and speed } \\
\text { of its transmission }\end{array}$ \\
\hline Time-consuming consensus building & $\begin{array}{l}\text { Risk of disintegration of network } \\
\text { entrepreneurial structure due to withdrawal of } \\
\text { key actors }\end{array}$ \\
\hline Need to prepare actors for effective interaction & $\begin{array}{l}\text { High dependency on performance and } \\
\text { operability of platform solutions }\end{array}$ \\
\hline
\end{tabular}

effect is realized due to the active information and economic transactions, which allow forming and achieving common goals. To achieve the goals of sustainable development in economic, social and environmental aspects, such a structure compared to the dependent focal network has less flexibility at the initial stage of development due to differences in the scale of companies, their corporate cultures, quality of goods and services, technology, as well as the propensity of actors to fractiousness. However, the acceptance of compromise decisions at the expense of coordination and the general control, development of interaction within a set of uniform requirements, allows effective functioning of independent ecosystems.

Dependent focal networks are formed of actors completely dependent on the organizer of the ecosystem platform or partly dependent when applying the business model of franchising. For the purposes of sustainable development, such model has advantages in the formation of pricing, social or environmental policies. However, if they dominate the market, there is a threat of limiting access to potential customers for companies outside the ecosystem, thus violating the rules of competition. Smaller players or new market entrants with 


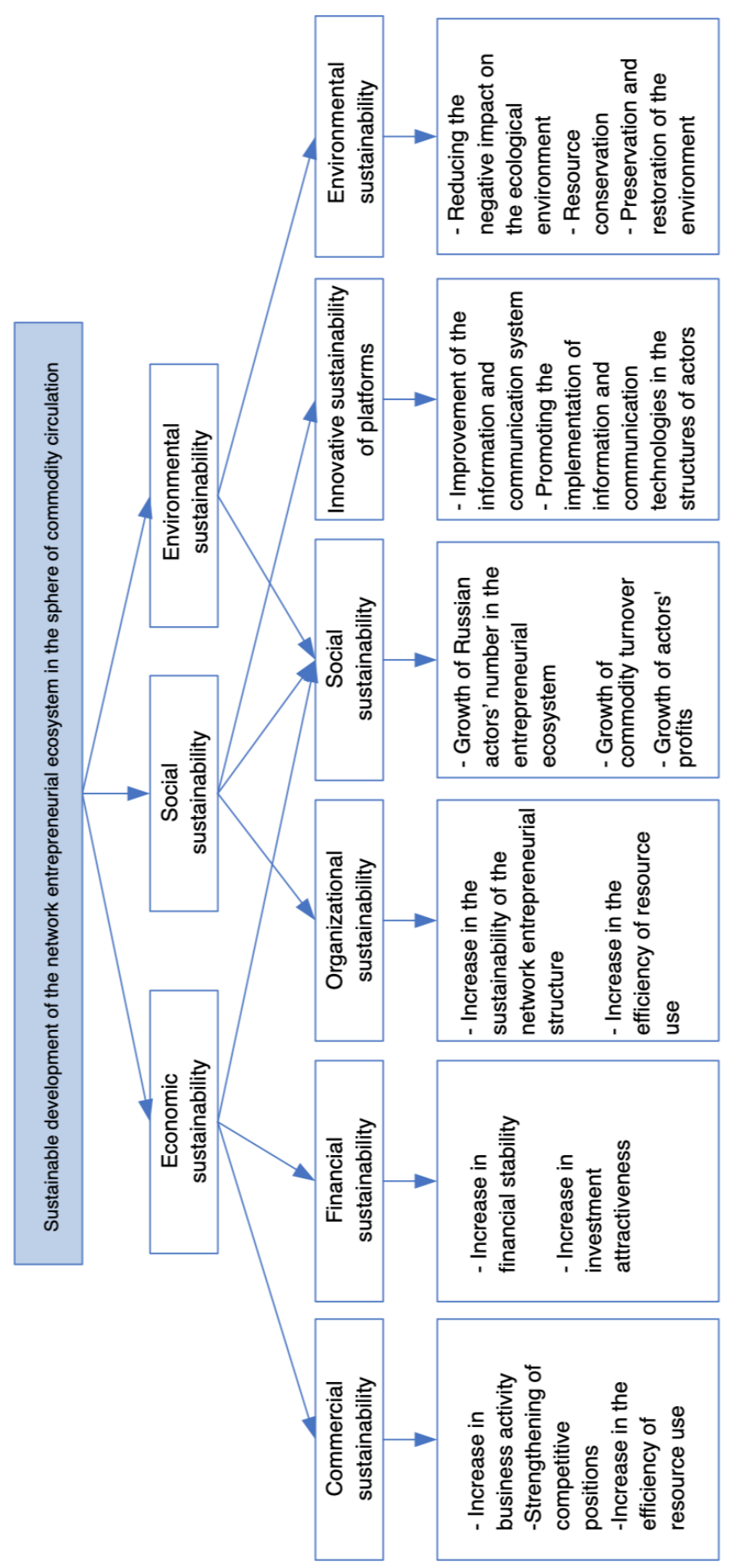

Figure 2 Tree of goals of a commodity circulation ecosystem that implements the principles of sustainable development

growth potential, providing goods and services of higher quality, creating unique value propositions, in most cases are unable to compete with the platform ecosystem or reach a level that allows them to compete in an environment dominated by the ecosystems.

The development of the platform-based ecosystem requires an assessment of the risks of monopolization, the 


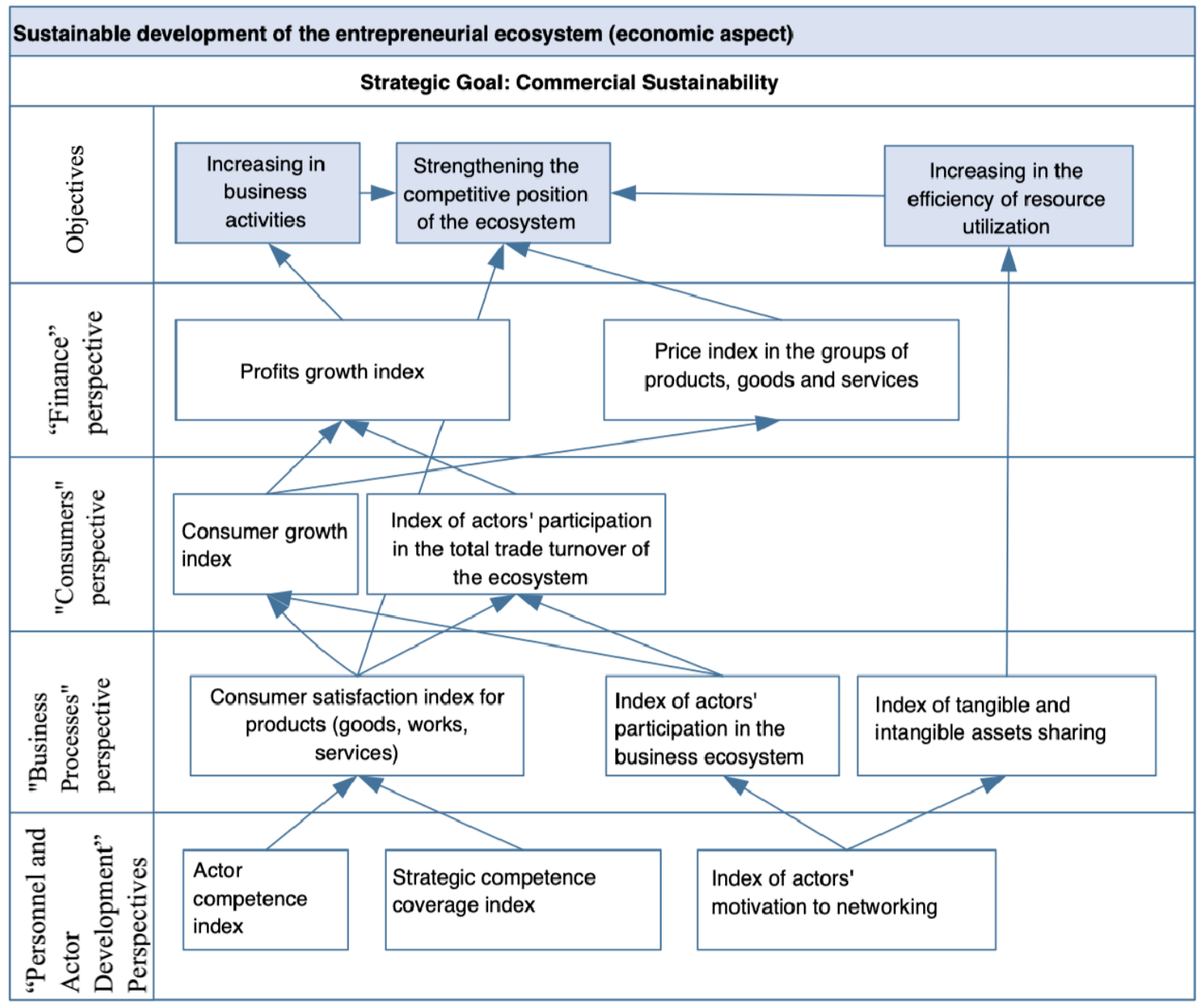

Figure 3 Key evaluation indicators for the "Commercial Sustainability" goal

benefits for actors and consumers, the definition of directions and the level of transformation of the competitive environment for manufacturers and other market participants outside the ecosystem (Table 2).

Consideration of these circumstances allows the choice of indicators; it should take into account the possibility of assessing the effectiveness of interaction within platform solutions for each actor of the network structure, for the ecosystem as a whole, and for the organizer of the platform.

For every actor within the ecosystem, it is expedient to carry out the analysis of transaction costs and indicators of development. For companies in different sectors of economy, indicators may differ, but should correspond to the sustainable development objectives of the entrepreneurial ecosystem as a whole.

The indicators of economic activity of actors within the ecosystem should correspond to the inequality 1 :

$$
E_{\mathrm{P}}-\mathrm{TI} I_{\mathrm{p}}<E_{\mathrm{c}}-\mathrm{TI} I_{\mathrm{c}}
$$

Where:

$E_{\mathrm{P}}-$ Overall effect of the activity of an economic agent in market transactions;

$E_{\mathrm{c}}$ - Overall effect of the activity of an economic agent in a network entrepreneurial structure;

$\mathrm{TI}_{\mathrm{p}}$ - Transaction costs of an economic agent in the context of market interaction;

$\mathrm{TI}_{c}-$ Transaction costs of an economic agent in a network entrepreneurial structure.

It is obvious that the effect of participation and interaction in an ecosystem should exceed the effect of market transactions; from the position of the ecosystem organizer, it will increase the actors' motivation to interact both horizontally and vertically, and to adopt the values common to the ecosystem.

For an entrepreneurial ecosystem as a whole and its participants, it is necessary to take into account the 


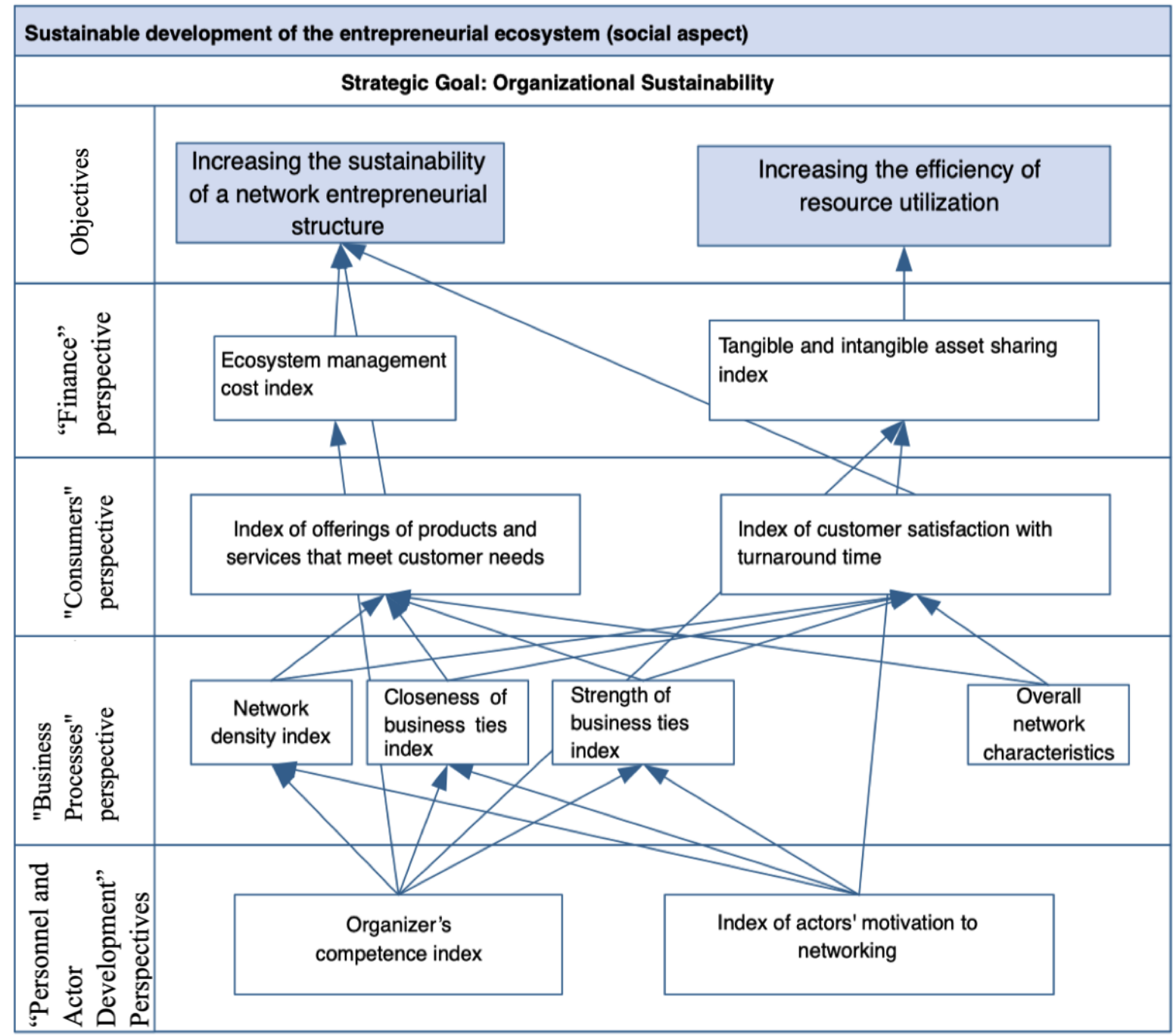

Figure 4 Key evaluation indicators for the goal "Organizational sustainability"

following: (1) the specifics of the platform-based ecosystem; (2) the specifics of the actors in this sector of economy; (3) the need to implement the concept of sustainable development; (4) customer satisfaction with their relations with the ecosystem.

The system of indicators is based on the following principles:

1. The principle of trinity of strategic goals in the ecosystem in economic, social and environmental aspects (Figure 2).

2. The purpose decomposition principle in directions of activity of an enterprise ecosystem broken down to such perspectives as "Finance", "External consumers", "Business processes", "Personnel".

3. Principle of solidarity support of strategic goals in an ecosystem by actors and the organizer.

4. The principle of development and preservation of the value of ecosystem services (Table 1) and its sustainable development in the interests of actors and end users (Figure 2).

When forming the system of indicators, we take into account (1) ease of use for a wide range of users; (2) unambiguous interpretation of the dynamics of the composite index; (3) possibility to trace the contribution of ecosystem actors to the dynamics of the composite index; (4) ease of adding new indicators.

An example showing the formation of a system of indicators in the context of commercial sustainability as one of the subgoals of the ecosystem is shown in Figure 3. This group of indicators can be recommended for actors, organizer and ecosystem as a whole, as it fully corresponds to the (principles of the trinity of goals, decomposition of goals, solidarity support of strategic goals of ecosystem, sustainable development in the interests of consumers.

Organizational sustainability is a characteristic that reflects the activity of the organizer of the ecosystem platform. The system of evaluation of its activity includes 
indicators, which underlie the formation of the main advantages of the ecosystem: the joint use of tangible and intangible assets, the level of customer satisfaction (external and internal) - Figure 4.

\section{CONCLUSIONS}

The goal of meeting consumer needs in various sectors of the economy is influenced by the processes of information and communication globalization and digitalization, as well as by specific trends and patterns of the economy sector.

The development of digital economy causes transformations in the technologies, interaction patterns and models of competitiveness of the enterprises. Networking, the use of the online channels, and the distributed use of assets and resources are among the most significant development trends.

Network technologies, which have emerged and developed with the spread of mobile devices and Internet, not only make it easier for users to find goods and services, but also allow companies to collect and accumulate information about purchase history and customers' behaviour. This information can be used to form a personalized offer to the customer and assess the reliability and importance of the business partner. A significant amount of information is also formed by ecosystem actors, which using the proposed system of indicators make it possible to assess the effectiveness of actors' participation and interaction in the platform-based ecosystems, as well as assess the sustainability of the entrepreneurial ecosystem as a whole.

\section{AUTHORS' CONTRIBUTIONS}

All co-authors contributed to the design and implementation of the research, to the analysis of the results and to the writing of the manuscript.

\section{REFERENCES}

[1] R. Adner, Ecosystem as structure: an actionable construct for strategy, in: Journal of Management, 43(1) (2017) pp. 39-58. DOI: https://doi.org/10.1177/0149206316678451.

[2] L. Araujo, H. Kjellberg, R. Spencer, Market practices and forms: Introduction to the special issue. Marketing Theory, 8(1) (2008) pp. 5-14. DOI: https://doi.org/10.1177/1470593107086481.

[3] H. Kjellberg, F. Azimont, E. Reid, Market innovation processes: Balancing stability and change. Industrial Marketing Management, 44 (2015) pp. 4-12. DOI: https://doi.org/10.1016/j.indmarman.2014.10.002.
[4] C. Mele, J. Pels, K. Storbacka, A holistic market conceptualization. Journal of the Academy of Marketing Science, 43(1) (2015) pp. 100-114. DOI https://doi.org/10.1007/s11747-014-0383-8.

[5] S. Nenonen, K. Storbacka, A. Sklyar, P. Frow, A. Payne, Value propositions as market-shaping devices: A qualitative comparative analysis. Industrial Marketing Management, 2019. https://doi.org/10.1016/j.indmarman.2019.10.00. DOI: https://doi.org/10.1016/j.indmarman.2019.10.006

[6] A. Venkatesh, L. Peñaloza, A. F. Firat, The market as a sign system and the logic of the market. The service-dominant logic of marketing, 2006, pp. 251265. DOI: https://doi.org/10.1007/s11747-0070069-6.

[7] L. Aarikka-Stenroos, P. Ritala, Network management in the era of ecosystems: Systematic review and management framework. Industrial Marketing Management, 67 (2017) pp. 23-36. DOI: https://doi.org/10.1016/j.indmarman.2017.08.010.

[8] M. Fourcade, Theories of markets and theories of society. American Behavioral Scientist, 50(8) (2007) pp. 1015-1034. DOI: https://doi.org/10.1177/0002764207299351

[9] K. Möller, A. Halinen, Managing business and innovation networks-From strategic nets to business fields and ecosystems. Industrial Marketing Management, 67 (2017) pp. 5-22. DOI: https://doi.org/10.1016/j.indmarman.2017.09.018

[10] F.K. Akhmedzyanova, I.V. Galantseva, A.L. Yushchenko,Bulletin of Kazan Technological University, $14 \quad$ (2013). https://cyberleninka.ru/article/n/analizpredprinimat elskoy-sredy-regionov-rossii-1.

[11] R.V. Gibadullin, R.I. Malikov, K.E. Grishin, D.D. Mukhametova, Institutional configuration of the regional business environment as a factor of competitiveness of business structures, Russian Entrepreneurship,17 (2017) pp. 2505-2526. DOI: https://doi.org/10.18334/rp.18.17.38282.

[12] O.V. Saginova, O.A. Grishina, D.A. Shtykhno, Project-based learning of students on the basis of orders of small and medium entrepreneurial structures, Russian Entrepreneurship, 18(3) (2017) pp. 417-425. DOI: https://doi.org/10.18334/rp.18.3.3730.

[13] S.V. Levushkina, Integrated set of factors of entrepreneurial environment and trends of their development. Modern research of social problems. http://www.sisp.nkras.ru. 
[14] L.A. Ramenskaya, Application of ecosystems concept in economic and managerial research, Manager, $11(4$ (2020) pp. 16-28. DOI: https://doi.org/10.29141/2218-5003-2020-11-4-2.

[15] Piyush Kumar, Mayukh Dass, Shivina Kumar, From competitive advantage to nosal advantage: Ecosystem structure and the ne five forces that affect prosperity, Business Horizons, 58 (2015) pp. 469481.

DOI: https://doi.org/10.1016/j.bushor.2015.04.001.

[16] S.V. Doroshenko, A.G. Shelomentsev, Entrepreneurial ecosystem in modern socioeconomic research, Journal of Economic Theory, 4 (2017) pp. 212-221. DOI: https://doi.org/10.17122/2541-8904-2019-4-30134-140.

[17] P. Macedo, L. Camarinha-Matos, An analysis of value system alignment in collaborative network management. Approx, 7 (2017) pp. 1231. https://doi.org/10.3390/app7121231.

[18] A.N. Asaul, E.G. Skumatov, G.E. Lokteeva, Methodological aspects of formation and development of entrepreneurial networks. $\mathrm{SPb}$.: Humanistika, 2004, pp. 256.

[19] A.V. Volkov, M.G. Svetunkov, Methods of evaluation of entrepreneurial networks, Kazan Economic Bulletin, 6(8) (2013) pp.79-84.

[20] E.M. Mezentsev, Development of the system of network interactions of business entities. Thesis for the degree of Candidate of Economic Sciences. Yekaterinburg. 2020, p. 160.

[21] M.V. Vysochina, A.I. Sulyma, Development of a methodical approach to assessing the sustainable development of integrated business structures, Scientific Bulletin: Finance, Banks, Investments, 1 (2020) pp.150-157.

[22] Human Development Index (HDI). http://hdr.undp.org/en/content/humandevelopment-index-hdi.

[23] Global Multidimensional Poverty Index (MPI). http://hdr.undp.org/en/2020-MPI.

[24] Human Development Data (1990-2018). http://hdr.undp.org/en/data

[25] V.A. Veselov, Ensuring sustainable development of entrepreneurial structures on the basis of integration. Dissertation for the degree of Candidate of Economic Sciences. Saint-Petersburg. 2007, p. 211. 